\title{
Between science and magic: the case of Schopenhauer
}

\author{
Entre ciência e magia: o caso de Schopenhauer
}

\section{Marco Segala*}

\begin{abstract}
A philosophical reflection about the phenomenology represented by magic and extraordinary mental powers should involve a consideration about the history of philosophy, in particular of those philosophers who were acquainted with the paranormal and investigated into it. The present paper proposes a reading of Schopenhauer's investigation into paranormal phenomena which involves three aspects: an analysis of the argumentative strategies proposed by Schopenhauer; a contextualization of Schopenhauer's treatment of magic and spiritism; a tentative interpretation of that treatment as a link between the traditional interpretation of the paranormal and the new scientific approach by the psychic research of the late 19th century.
\end{abstract}

Keywords: Schopenhauer's Philosophy; Animal Magnetism; History of Neurophysiology; History of Parapsychology

Resumo: Uma reflexão filosófica sobre a fenomenologia representada pela magia e pelos poderes mentais extraordinários deveria envolver uma consideração sobre a história da filosofia, em particular sobre os filósofos que estavam familiarizados com o paranormal e que investigaram sobre ele. $\mathrm{O}$ presente trabalho propõe uma leitura sobre a investigação de Schopenhauer acerca dos fenômenos paranormais a qual envolve três aspectos: uma ảnálise das estratégias argumentativas propostas por Schopenhauer; uma contextualização do tratamento dado por Schopenhauer à magia e ao espiritismo; uma tentativa de interpretação desse tratamento como um vínculo entre a interpretação tradicional do paranormal e a nova abordagem científica através da pesquisa psíquica do final do século XIX.

Palavras-chave: Filosofia de Schopenhauer; Magnetismo Animal; História da Neurofisiologia; História da Parapsicologia

\section{Introduction}

A philosophical reflection about the phenomenology represented by magic and extraordinary mental powers should involve a consideration about the history of philosophy, in particular of those philosophers who were acquainted with the paranormal and investigated into it. Such a consideration, moreover, should contemplate the historical contexts and acknowledge that in the philosophical study of magic a line of separation can be drawn in the last quarter of the 19th century, when the scientific method was applied to the research on the paranormal and spiritism became a scientific object of investigation as defined by the new discipline of parapsychology. Bergson's interest in hypnotism in the 188 os cannot be examined and assessed by the conceptual instruments we would use in the case of Kant's analysis of Swedenborg's magic one century before or Schopenhauer's chapter on magic in On Will in Nature in 1836.

The present paper starts from this premise and proposes a reading of Schopenhauer's investigation into paranormal phenomena which involves three aspects: an analysis of the argumentative strategies proposed by Schopenhauer; a contextualization of Schopenhauer's treatment of magic and spiritism; a tentative interpretation of that treatment as a link 
between the traditional interpretation of the paranormal and the new scientific approach by the psychic research of the late 19th century.

The first aspect involves an analysis of Schopenhauer's arguments that are usually overlooked by scholars. The fact that Schopenhauer believed in the paranormal and explained it by the metaphysics of the will has typically oriented commentators to dismiss Schopenhauer's approach as non-argumentatively sustained. His credulity in extraordinary phenomena seems a preconception that has little to do with a rational and argumentative approach. One could argue that if we pay attention to the historical context, a judgement on Schopenhauer's credulity from the point of view of the 21st century interpreter would be misplaced. But without starting this kind of discussion, the point is that Schopenhauer actually argued - to be exact, he offered two kinds of arguments, and their differences deserve to be clarified. This is the main aim and contribution of the first section.

The second aspect is typically confronted by scholars who address the issue of magic and paranormal as developed at the time of classical German philosophy ${ }^{1}$. One common feature of these historical and contextual studies is the focus on philosophical or literary texts and a certain lack of attention to the scientific literature and sources that guided the German philosophers' analyses and assessments of the paranormal. Even if very succinctly, in the second section I'll try and fill this gap in the case of Schopenhauer - as I am convinced that without considering the scientific research developed in the first half of the 19th century most of what Schopenhauer wrote about the paranormal would remain obscure and unfounded ${ }^{2}$.

The third aspect addresses an issue which is only marginally mentioned by historians who investigate the new approach to the paranormal at the time of the rise of psychic research in the last quarter of the 19th century, namely the role of Schopenhauer in that process. The third section of this paper offers an initial, tentative contribution in the hope that it might open a new line of research. I'm aware that analysing the legacy of Schopenhauer's writings on the paranormal in Germany, France, and Great Britain requires more than a few paragraphs. My intention is not to offer answers, but to suggest a question, in order to introduce a new subject of investigation and to provide some supporting hints that might be stimulating for a new line of research. It is usually admitted that Schopenhauer was extremely influential in the development of the sciences in the second half of the 19th century, but very little has been offered to prove such a shared conviction. Schopenhauer's presence in the minds and intentions of the founders of the psychic societies would constitute intriguing evidence.

\section{Schopenhauer's Arguments}

Schopenhauer followed two different strategies to discuss the paranormal. The first one, as pursued in the chapter "Animal magnetism and magic" in On Will in Nature (1836), was defined by the notion of corroboration (Bestätigung): as "in animal magnetism and in other things, we see will - which I have presented as the thing in itself, as the only real thing in all existence, as the core of nature [...] - then I know of no more factual corroboration of my theory that could still be required" ( $\mathrm{N}, 104 / 409)$. The paranormal was "certainly a strong, empirical confirmation of my theory that the metaphysical as such, the only thing existing

\footnotetext{
${ }^{1}$ Among the several contributions, see for example Ego 1991, Sawicki 2002, Treitel 2004, Andriopoulos 2013.

${ }^{2}$ An extensive analysis of Schopenhauer's scientific sources, mainly in the field of neurophysiology, can be found in Segala 1998, chapter 4.
} 
beyond representation, the thing in itself of the world, is none other than that which we know in ourselves as will" ( $\mathrm{N}, 115 / 418)$. In conclusion, the paranormal was to be considered "as practical metaphysics" to be related to "the theoretical metaphysics that [...] could be no other than my resolution of the world into will and representation" (N, 127/429).

Such an interpretation of the paranormal as corroboration required the demonstration that the metaphysical view of the world as will provided the ultimate explanation for the many phenomena related to animal magnetism and magic. In the chapter "Animal magnetism and magic" this argument was articulated in three steps: 1) assessment of the empirical basis; 2) inquiry about a possible philosophical interpretation of the extraordinary phenomena; 3 ) identification of the only metaphysical entity - the will able to explain those phenomena and correctly interpret their manifestation.

Schopenhauer's argument started from acknowledging as credible that the operators of animal magnetism were able to induce physical and psychical alterations in patients and that the phenomena traditionally considered as magic efficaciously intervened in and modified the normal course of the events. He appealed to the evidence produced by the many publications in the field of medicine and scrutinized by researchers - and specified that "science ensures at the same time that the pendulum does not again receive too strong an impulse towards the opposing side, and that we could not be cast back into the superstition of ignorant times" ( $\mathrm{N}, 107 / 411)$. It seems clear that 1$)$ he appreciated that science would support evidence without promoting new forms of superstition and Schwärmerei and that 2) he maintained a rationalist method in filtering and assessing evidence and facts which "empirically confirm the possibility of a magical, as opposed to a physical effect" (N, 107/411). We can certainly consider him naïve, but I would be cautious about his "willingness to uncritically accept paranormal phenomena at face value"3. As a matter of fact he did not seem eager to wed the cause of magic, as it appears from this warning: "nonetheless nowhere is it more necessary than here that we be cautious to fish isolated truths out of the confusion of lies, deceit, and nonsense [...]. For lies and deception, common everywhere in the world, nowhere have such free play than where the laws of nature are admittedly forsaken, and indeed are declared to be suspended" (N, 108/412).

Once verified that there was a reliable empirical basis for admitting the credibility of phenomena related to animal magnetism and magic, it seemed evident that those phenomena were not explained by science, natural laws, and causality. They challenged the norms of nature's operations and displayed events "that to a certain extent suspend [the law of causality] and actually exert action at a distance, revealing a supernatural, i.e., metaphysical mastery of nature" (N, 104/409). Then Schopenhauer approached the second step of his argument: as there was not a natural interpretation supported by science, it was necessary to look for the possibility of a different explanation, provided by philosophy. Kant's doctrine of the distinction between appearances and things in themselves would indicate the alternative path to follow: the existence of a metaphysical nexus. Beyond "the external connection which is the basis for the physical nexus, there must be still another, proceeding through the essence in itself of all things, a subterranean connection, so to speak, whereby one point of appearance would be able immediately to affect any other by a metaphysical nexus; that therefore it must be possible to affect things from within, instead of from without as is usual, an effect of appearance on appearance by means of the essence in itself that is one and the same in all appearances" ( $N, 111 / 415)$. Magic and extraordinary phenomena are possible only admitting that "the physical means applied are always taken as a vehicle for something metaphysical" $(\mathrm{N}, 112 / 416)$.

\footnotetext{
${ }^{3}$ Cartwright 2020, 186.
} 
The third part of the argument was designed to establish the possibility of singling out the metaphysical entity through an inference to the best explanation. Schopenhauer remarked that all of those who spoke about magic and animal magnetism would mention the operator's power of the will and provided many quotations to support this claim. It seemed that there was a consensus on the fact that "we recognize in the few facts that speak for the reality of magic (specifically animal magnetism and sympathetic cures) nothing but an immediate effect of will that here expresses power outside the willing individual, which otherwise would be expressed inside and [...] we see that [...] those more deeply initiated in ancient magic derived all magical effects from the will of the magician" (N, 115/418). Analogously, animal magnetism showed that the real agent "is nothing else than the will of the magnetist" ( $\mathrm{N}, 100 / 405)$. But as the individual will is nothing but expression of the more essential metaphysical will, this conclusion followed as "certain: that an anticipation of my metaphysics underlies all of the attempts at magic that have been made, be they successful or unsuccessful, as in them the awareness was expressed that the causal law is only the bond of appearance, but the essence in itself of things remains independent from this law; and that, if from this essence, that is, from within, an immediate effect on nature is possible, it could be brought about only through will itself" ( $N$, 126/429). A corollary of the metaphysical explanation was that paranormal phenomena had the ability "to suspend the isolation in which will finds itself in every individual [and] to achieve an increase of the immediate sphere of will beyond the body of the one willing" $(\mathrm{N}, 112 / 416)$.

The second argumentative strategy was pursued and developed in the chapter "Essay on Spirit Seeing and Everything Connected Therewith" of the first volume of Parerga and Paralipomena. It was quite different from the one in On Will in Nature and did not follow a step-by-step argument. It analysed instead a series of topics related to philosophy (epistemology and metaphysics) and science which would suggest explanations of the paranormal and would converge towards the justification of the belief in those kinds of phenomena. The general strategy was simple and direct: facts about extraordinary phenomena remain doubtful - notwithstanding they were "corroborated by the consistency of hundreds of cases of the most trustworthy evidence" PI, 293/263) - because we do not have a satisfying rational explanation about them; by providing a constellation of explanations - based on idealism, metaphysics of will, and physiology - we shall find the paranormal as credible and even convincing. Idealism showed that paranormal and ordinary phenomena were alike - representations; metaphysics of will explained the real nature of the paranormal; physiology explained the paranormal as operations performed by the nervous system and classified the different kinds of extraordinary phenomena.

Two aspects deserve attention when we recapitulate the argumentative structure of the "Essay on Spirit Seeing": the weight of the scientific discourse - provided by the relevance of the physiological explanation of paranormal phenomena - and the integration of science with epistemology and metaphysics. This latter aspect was openly pursued by the structure of the essay and the juxtaposition of its different elements: philosophy, the discussion of alternative scientific hypotheses and their pros and cons, and the final scientific theory. The essay defined the epistemological and metaphysical explanation of the paranormal, it analysed different but unsatisfying scientific hypotheses and established the requirements of a convincing scientific explanation, and finally it proposed a scientific theory that satisfied the epistemological requirements and closed the investigation while showing a meaningful integration with philosophy.

On the philosophical side, Schopenhauer emphasised his connection with Kant - the doctrine of Vorstellung clarified Kant's notion of Erscheinung and the metaphysics of the will completed Kant's inquiry into the nature of the thing in itself (PI, 298/268) - and his 
own philosophical views about idealism - the world as representation - and metaphysics the world as will - as providing the necessary explanation of the paranormal. The idealistic doctrine of representation justified the possibility of extraordinary phenomena as produced by the intellect in the same way of ordinary phenomena: "our intuitive perception of the external world is not merely a question of the senses, but is mainly intellectual, in other words, is (objectively expressed) cerebral. [...] This is the transcendental standpoint the result of which might possibly be that ideality attached to the spirit apparition neither more nor less than to the bodily phenomenon" (PI, 254/228-9). As we recognize "the will to be this thing-in-itself, this enables us to suppose that perhaps such a will underlies both spirit and bodily phenomena" (PI, 255/229). Moreover, the metaphysical will would explain the possibility of overcoming the laws of nature and representation, as the will was not constrained by the limits of space, time, and causality: "time and space no longer separate individuals and their separation and isolation, which are due to those very forms, no longer place insuperable barriers in the way of the communication of thoughts and the direct influence of the will" (PI, 295/265) ${ }^{4}$.

On the scientific side, the inquiry was complex and mainly revolved around the physiology of the brain and the nervous system. Having established the idealistic view, the main question was "whether images or pictures of intuitive perception can actually arise in our intuitively perceiving intellect or brain, complete and indistinguishable from those caused therein by the presence of bodies that act on the external senses, and yet without such influence" (PI, 256/229). The dream provided the best example of this possibility and "removes all doubt on this point" (PI, 256/230). A particular kind of paranormal phenomena - those related to somnambulism - showed that sleeping and dreaming could be a promising starting point for a physiological investigation about the operations of the brain and the nervous system when paranormal phenomena showed up. The first step of such an investigation focused on what happens when we dream. It seemed that the organism had the power to feed the brain with sensory-like stimuli and to alter its activity - thus originating representations from within: "the brain can be influenced by stimuli coming from the interior of the organism to perform its function of intuitively perceiving forms that fill space. For phenomena that have originated in this way will be quite indistinguishable from those that are occasioned by sensations in the sense-organs which were produced by external causes" (PI, 265-6/236).

The second step of the scientific inquiry was to discard as insufficient the hypothesis "that the state of somnambulism consists in the complete removal of the brain's power" (PI, 269/242). Another unconvincing possibility was that the extraordinary operations performed by a somnambulist were the effect of an extraordinary activation of the normal functions of the central nervous system, stimulated by the senses through the mediation of an internal sensorium (PI, 270-2/242-4). Schopenhauer criticised other modifications of these hypotheses and eventually proposed his theory: as the activity of the brain during sleep is stimulated from within, the stimulating waves move in the opposite direction with respect to the ordinary sensorial stimulation. Thus "the brain now works the other way round" (PI, $278 / 250$ ) and hence the peculiarity of somnambulism and its clarity: "the dream-organ is, therefore, the same as the organ of conscious wakefulness and intuitive perception of the external world, only grasped, as it were, from the other end and used in the reverse order" (PI, 279/251).

The third step was the extension of this physiological explanation to include animal magnetism (PI, 287-293/258-63) and magic (PI, 293-5/263-5) and all of the paranormal

${ }^{4}$ See also PI, 293-4/264, 296-7/266, 335/301. 
phenomena, and thus concluding that "animal magnetism, sympathetic cures, magic, second sight, dreaming the real, spirit seeing, and visions of all kinds are kindred phenomena, branches of one stem. They afford certain and irrefutable proof of a nexus of entities that rests on an order of things entirely different from nature" (PI, 295/265). Like any other natural force, which was a manifestation of the unstoppable activity of the metaphysical will, the physiological dynamics of the nervous system manifested the same order of things and found its ultimate explanation in the metaphysics of will - specifically, in "the view that the body is wholly identical with the will and thus is nothing but the will's image arising in the brain" (PI, 275-6/247).

This excursus on the themes which Schopenhauer employed in the chapter "Animal magnetism and magic" and in the "Essay on Spirit Seeing" shows that, notwithstanding the similarity of the subject, they actually provided two different views. They had different aims, were structured in different ways, and, above all, resorted to different kinds of arguments. The chapter in On Will in Nature assembled evidence from an impressive quantity of literature which, he believed, established that the paranormal was credible and, most importantly, corroborated the metaphysics of will. The essay in Parerga and Paralipomena was much more complex: less interested in revisiting the evidence provided by the literature, it considered the paranormal as a matter of philosophical and scientific inquiry. It was a subject that required an explanation, and in particular a scientific explanation to be coupled with the philosophical one.

This is an aspect which is overlooked by the studies about this peculiar subject. Generally, they consider that the two chapters deal with the same theme and can be assessed together ${ }^{5}$. My thesis is that this approach misses the fact that on the one hand the text in On Will in Nature was eminently related to a particular aspect of Schopenhauer's philosophy of science - the one associated with the notion of Bestätigung ${ }^{6}$. On the other hand, the "Essay on Spirit Seeing" explored the possibility of re-establishing the project of philosophy of nature developed in the first volume of The World as Will and Representation. This appears when we appreciate the presence of the notion of Polarität in the in the "Essay" as "the universal law of polarity" (PI, 291/261). Polarity instantiated in the phenomenal world the dynamics of the Objektivation des Willens, the fundamental notion of Schopenhauer's philosophy of nature in his system. Philosophy of nature intended to elaborate the metaphysical truth that the will is the thing in itself into a comprehensive view of the world that would both refute philosophical notions like reductionism and materialism (as in PI, 297/267) and integrate scientific knowledge and philosophically explained scientific concepts like natural forces, natural laws, and the foundation of life.

\section{Historical context and science}

Once we have acknowledged that the two texts pursued different goals, it is possible to appreciate the reason why they involved two kinds of argumentation. At the same time, it seems less convincing to criticise them because of the credulity Schopenhauer showed while discussing extraordinary phenomena. In Die Zerstörung der Vernunft (1954), György Lukács strengthened his accusation of irrationality against Schopenhauer by a cursory analysis of the "Essay" as a demonstration of "blind credulity in the appraisal of occultism" against an

\footnotetext{
${ }^{5}$ See for example Andriopoulos 2013 and Cartwright 2020.

${ }^{6}$ See Segala 2010.
} 
unsubstantiated "agnosticism" about natural laws7. If one follows the argument designed by Schopenhauer in the "Essay", it appears evident that he was not a sceptic about the explicative power of the sciences - rather he was looking for a scientific explanation of the paranormal. That, together with the conviction about having discovered the metaphysical truth behind phenomena, brought him to a comprehensive theory of the paranormal. Of course, he believed that paranormal phenomena occurred, but it was not an irrational belief. He had witnessed them and read a lot about them, and his research was motivated by not being entirely satisfied with such evidence. Only a complete, philosophic-scientific explanation would have a final word on the subject.

Such a view, however, does not answer the question about the legitimacy of Schopenhauer's arguments, which were based on the assumption that paranormal phenomena are real. A non-believer might certainly dismiss all of Schopenhauer's arguments as based on false premises and conclude that discussing about the paranormal is per se irrational. In fact, there is no definitive rational motive to believe in extraordinary phenomena. There is evidence, but evidence is often questionable, and in the end it is not enough to gather a general consensus - this is the reason why the subject is still debated and under scrutiny today. But we are not arguing about the reality of the paranormal. We are discussing Schopenhauer's ability to provide good arguments - to do that we need to understand whether he had enough reasons to assume that the evidence he provided was enough to believe in the paranormal and to start a philosophical-scientific research about the extraordinary.

The claim I want to defend is that without a proper understanding of the historical and biographical context in which Schopenhauer carried out his research, our assessment of his arguments would fail, as it would be dependent on our contemporary views about the paranormal. The merit of the contextual approach is that it would provide a reason not to be embarrassed by Schopenhauer's choice of the themes of magic and animal magnetism - or to condemn it as irrational.

Let's start with the general context. The intention to discern reality and honesty from fantasy and cunning in the domain of animal magnetism and related phenomena was not the prerogative of dreamers or artists with an irrational penchant. Franz Anton Mesmer, the founder of animal magnetism, obtained his greatest success in the pre-revolutionary Paris, at the time the capital of the European Enlightenment ${ }^{8}$. Several physicians and philosophers in the German countries embraced the magnetic medicine, as aptly summarised by Henri Ellenberger: "mesmerism constantly progressed in Germany. From 1790 to 1820, it [...] gained a foothold at the universities of Bonn and Berlin. Well-known physicians such as Wolfart, Hufeland, and Reil were convinced of its validity. [...] The promoters of the Philosophy of Nature hailed magnetism as an epoch-making discovery" (Ellenberger 1994, 159)9. Together with mesmerism, the belief in ghosts, communication with the dead, and clairvoyance spread among intellectual circles and the scholarly world ${ }^{10}$. There was hesitation and scepticism among naturalists and scientists, and Kant and Goethe discussed the subject with distance and even coldness, but several physicians were favourably impressed by the paranormal. Among the philosophers, Schopenhauer was not alone in taking seriously the subject: Fichte, Schelling, and Hegel shared the same beliefs.

In addition to these contextual considerations, Schopenhauer's biography adds more elements and provides an even better characterisation of his motives in confronting those

\footnotetext{
${ }^{7}$ Lukács 1973, 207.

8 See Darnton 1968.

9 See also the more detailed Ego 1991.

${ }^{10}$ See Sawicki 2002 and Andriopoulos 2013.
} 
issues, starting with animal magnetism. When he lived in Berlin - between 1811 and 1813 as a student and in the 1820 s as a Privatdozent - he had several occasions to assess animal magnetism by the direct knowledge of physicians and scientists who were arguing about the reliability of magnetic cures.

Animal magnetism became a sensitive issue in Berlin following the activism of some members of the Berlin Academy of Science and professors of medicine at the University - in particularly Christoph Wilhelm Hufeland, who in March 1812 convinced the government to establish a scientific commission for the evaluation of magnetic medicine. Among the members were the physicist Paul Erman and the chemist Martin Heinrich Klaproth, who at the time were Schopenhauer's teachers. Their strong opposition was an obstacle to the positive pronouncement of the commission, as expected by Hufeland, but the contest did not stop and was later revived through the intervention of two other physicians and practitioners of the magnetic medicine - Johann Ferdinand Koreff and Karl Christian Wolfart, who were later appointed as professors of medicine at the University. The latter was a direct disciple of Mesmer and the editor of Mesmerismus (1814) - Mesmer's last publication, which presented animal magnetism as a general system of medicine providing health for the individuals and promising an ethical regeneration for society.

Koreff and Wolfart persuaded the Academy of science to announce a prize for the best essay devoted to animal magnetism. The commission appointed to judge the twentytwo proposed essays, however, was composed by academicians who strongly opposed the theory and practice of magnetic medicine, and in December 1821 they refused to award any essay. Another commission was appointed in 1824, but again without a definitive pronouncement. Notwithstanding the widespread and reiterated scepticism by the scientific community, it seemed impossible to discard the notion of extraordinary phenomena adduced by the magnetisers.

Schopenhauer witnessed all of these events and was in a close relationship with some of these protagonists. Among them, Erman - whose classes he attended as a student in 181112 and again in 1820-21, as a young philosopher interested in the physical sciences - and Wolfart, who in 1821 guided the new Privatdozent "into the dormitories of the somnambulists and was able to have long conversations with one of them"11. What did Schopenhauer think about all of this? He investigated the possibility of a scientific interpretation of animal magnetism in 1815, when he wrote a long annotation about a neurophysiological hypothesis inspired by the anatomical research on the nervous system of the physician and physiologist Johann Christian Reil ${ }^{12}$. The proposed explanation started from Reil's investigation into the interaction between the central nervous system and the "ganglionic system" (the autonomic nervous system), claimed that "in the body the organ of knowing is the brain, and in just the same way the ganglionic system corresponds to the will", and concluded that the process of magnetism "decreases the power of the brain and increases exclusively that of the ganglionic system" - thus putting the subject under the control of the will and freeing her "from all the limitations of individual" (HNI, 338/372).

Schopenhauer did not mention this hypothesis and the problem of the paranormal in the first volume of The World as Will and Representation - an indication of the fact that he was cautious and did not want to take a public position. He started a thorough reading of the literature devoted to the paranormal in the 1820s, and it was probably at this time that he became persuaded and became a believer, as the published chapter in On Will in Nature clearly shows. But was such a belief irrational? If we look at the contents of the dispute, we

\footnotetext{
${ }^{11} \mathrm{HNII}, \mathrm{XX} / \mathrm{xx}$.

${ }^{12}$ See HNI, § 502 and Reil 1807.
} 
can observe that on the one side there were the supporters of the facts who embraced the paranormal as real, while on the other side the sceptics claimed that without a scientifically sound theoretical frame those facts were disputable. It was the revival of a typical contraposition in the history of science - like the one which saw Robert Boyle opposing Isaac Newton in the second half of the 17th century - between empiricists and theoreticians. But this time it had a curious consequence: the former believed in spirit seeing, occultism, and magic, while the latter were called "doubters by profession"13.

Schopenhauer was certainly conquered by those facts, yet he was persuaded that facts required an explanation. His metaphysics provided one, but he never abandoned the idea that science, too, should offer its contribution. His former hypothesis of 1815 was not good enough. It encapsulated Reil's research on the relationship between the central nervous system and the autonomic nervous system, which seemed excellent both for distinguishing between intellect and will and explaining the primacy of the latter over the former. Yet, it did not solve the problem of the actual physiology of the paranormal: the two nervous systems seemed capable of interaction, but the physiological process activated by magnetism was not clear, and even less clear why in those circumstances the autonomic system would prevail over the other and direct the exceptional activities of an individual. Moreover, Schopenhauer was soon aware that other researchers contested Reil's idea of interaction: they viewed the two systems as different and did not admit the possibility of exchangeable functions. The ganglionic system could not substitute the brain and direct the marvellous operations of a somnambulist.

All this considered, it was a proof of adhesion to a sound methodological practice that Schopenhauer did not mentioned his former hypothesis in any publication and finally rejected it in the chapter of the Parerga. In the 1840s, a series of readings in the field of neurophysiology - including Pierre Flourens and Marshall Hall - convinced him that the central nervous system could be only partially active and nonetheless an individual could perform sophisticated tasks, like in the case of the somnambulist. Moreover, the research conducted by Rudolph Albert von Koelliker and published in 1844 discussed once again the possibility of an interaction between brain and ganglionic system. It admitted that the latter could perform specific and coordinated functions - thus guiding the activities of an individual - but pointed out that those functions were also governed by the central nervous system $^{14}$.

We are now in a good position to see that the question of whether Schopenhauer had good reasons to believe in the paranormal is not the right one, if we want to discuss his presumed rationalism. There is no decisive answer about that question: context and biography suggest that there were many reasons, but probably not enough to define them as good. His arguments in On Will in Nature were based on a series of assumptions, none of them derived from a model of scientific investigation. The approach in the Parerga essay, on the contrary, shows a major attention to the scientific methodology. Since the initial hypothesis of 1815 , the physiological explanation of the paranormal had been a requisite, but its elusiveness had curbed Schopenhauer's intention to publish. This aspect of the story,

\footnotetext{
13 This is Edgar Allan Poe's definition in the opening of the tale Mesmeric Revelation (1844), where he wrote: "Whatever doubt may still envelop the rationale of mesmerism, its startling facts are now almost universally admitted. Of these latter, those who doubt, are your mere doubters by profession - an unprofitable and disreputable tribe. There can be no more absolute waste of time than attempt to prove, at the present day, that man, by mere exercise of will, can so impress his fellow, as to cast him into an abnormal condition, of which the phenomena resemble very closely those of death, or at least resemble them more nearly than they do the phenomena of any other normal condition within our cognizance".

${ }^{14}$ See Flourens 1842, Hall 1840 and 1843, Koelliker 1844.
} 
then, answers positively another question, namely the one regarding Schopenhauer's adhesion to the standards of rationality established by the scientific method. Of course, one could say that he rationally confronted (and defended) a phenomenology that appeals to irrationalism - and could also reproach him of excessive enthusiasm in claiming the truth of the facts. But this kind of reproach is based on the assumption that those facts are false and disguise an intention to deceive. From this point of view, every research on the paranormal should be banned, not only Schopenhauer's.

My view proposes to assess both the readings I have provided about Schopenhauer's approach to these debatable topics - the argumentative and the historical. Both show that the two chapters he devoted to the paranormal - in 1836 and 1851 - were structured differently, had different intentions, and were developed on different paths. The chapter "Animal magnetism and magic" was assertive, emphasised facts, and put aside any form of doubt. The "Essay on spirit seeing" exhibited the healthy role of doubt, confronted the difficulties of finding a satisfying scientific explanation, and offered a theory. The only thing that did not change, with respect to the other text, was the belief in the paranormal. But believing (or not believing) cannot be judged as irrational per se, and Schopenhauer's credulity should not be judged weird or extravagant - neither at the time nor today.

\section{Legacy}

Belief in ghosts, magic, occult phenomena, and extraordinary powers have always been present among humanity. They were generally related to religions and their faith in a spiritual world existing beside or beyond the material one we live in. The Christian societies of the Western world found a way to accommodate beliefs in the extraordinary and sometimes to compartmentalise them. The theory of animal magnetism and the fame of Mesmer gave to the altered states of mind a new, non-religious meaning and made them a subject for discussions, especially in the domain of philosophy and medicine. After that, the English physician James Braid reinterpreted animal magnetism as "hypnotism" (1841), the extraordinary phenomena of mesmerisation found a more recommendable conceptual frame, and scientists became more and more interested in assessing the extension and powers of the mind.

In Great Britain, the turning point of this process was the foundation in January 1882 of the Society for Psychical Research in London. A group of philosophers, scholars, writers, physicists, and naturalists gathered with the purpose of rationally investigating paranormal phenomena and considering the possibility of extending the scientific methodology - thus including paranormal phenomena. It was the birth of parapsychology as a scientific inquiry into spiritism - as the paranormal was often commonly referred to. ${ }^{15}$ Immediately, two alternative views became evident: on the one hand, some pursued the notion of an ultimate unity between the visible and the invisible, matter and spirit, immanence and transcendence; on the other hand, some were more cautious and proposed investigations limited to the actual extraordinary activities of the mind, like telepathy or automatic writing. The former group admitted as crucial the analysis of the performances of the mediums who claimed to be in contact with the spirits of the dead and to be able to establish a communication between this world and the afterlife. Among them we can name the naturalist Alfred Russell Wallace and the physicists William Crookes and Oliver Lodge. The latter group - which numbered philosophers like Henry Sidgwick and William James -

\footnotetext{
${ }^{15}$ See Noakes 2019, chapter 2.
} 
dismissed the possibility of scientifically identifying disembodied and immortal souls. ${ }^{16}$ Sidgwick was adamant in warning against the difficulties of psychical research and detailed some common sources of error: corruption of the narratives by transmission or by time and prejudice in the observation of the facts ${ }^{17}$.

Beyond this main difference and other more nuanced positions, all of the members of the Society shared the idea that "the present is an opportune time for making an organised and systematic attempt to investigate that large group of debatable phenomena designated by such terms as mesmeric, psychical and spiritualistic", considering that "from the recorded testimony of many competent witnesses [...] there appears to be, amid much illusion and deception, an important body of remarkable phenomena which are prima facie inexplicable on any generally recognized hypothesis, and which if incontestably established, would be of the highest possible value"18.

A similar path towards institutionalisation was taken in France, where animal magnetism and hypnotism were the starting point of the new clinical approach to the mind by Jean-Martin Charcot and Hippolyte Bernheim - as analysed by Ellenberger's investigation into the birth of dynamic psychiatry ${ }^{19}$. Charcot associated with the physiologist Charles Richet, who in 1913 would be awarded with the Nobel prize in medicine for his research on anaphylaxis, in founding the Societé de Psychologie Physiologique and promoting investigations into spiritism. Richet became famous for his devotion to the research on ghosts and for having coined the term "ectoplasm" ${ }^{20}$. The strong interest in spiritism spread among scientists, physicians, and philosophers - like Pierre Janet and Henri Bergson - who from different perspectives considered the paranormal as a non-negligible and promising source for understanding the human mind. Bergson practiced hypnotism in the $188 \mathrm{os}$, in the 1900 promoted the activities of the Institut général psychologique - among which the experiments with the famous medium Eusapia Palladino ${ }^{21}$ - and in 1913 became president of the Society for Psychical Research and pronounced a famous presidential address, which confronted the methodology of parapsychological research.

Germany was no exception. In 1886 the Psychologische Gesellschaft was established in Munich with the same purpose and analogous methods of the Society for Psychical Research, namely the scientific inquiry into the paranormal, and a scientific journal Sphynx. Monatsschrift für die geschichtliche und experimentale Begründung der übersinnlichen Weltanschauung auf monistischer Grundlage ${ }^{22}$. Among its leading members, the philosopher Carl Du Prel was conducting a battle against materialism and its domain in the psychological sciences, in order to develop an experimental psychology that would provide alternative and less narrow views with respect to the programme developed by Wilhelm Wundt for a scientific psychology. The same approach was developed by the Berliner Gesellschaft für Experimental-Psychologie, founded in 1888, which promoted the idea of expanding the study of mental powers beyond the limits set by traditional scientific

\footnotetext{
${ }^{16}$ Scarpelli 1993, chapter 9.

${ }_{17}^{17}$ Sidgwick 1889, 4.

${ }_{18}$ This anonymous presentation of the Society manifesto rapidly spread and gained a lot of attention. The present quotation is from an essay in the American Popular Science Monthly by Butler 1886, 484

19 See Ellenberger, chapter 3. See also Nicole Edelman, "Spirites et neurologues face à l'occulte (1870-1890): una particularité française?”, in Bensaude-Vincent and Blondel, 2002, 85-104.

${ }^{20}$ See Pascal Le Maléfan, "Richet chasseur de fantômes: l'épisode de la villa Carmen”, in Bensaude-Vincent and Blondel, 2002, 173-200.

${ }^{21}$ See Christine Blondel, "Eusapia Palladino: la méthode expérimentale et la "diva des savants", in BensaudeVincent and Blondel, 2002, 143-72.

${ }^{22}$ In 1892-93 the journal underwent a radical transformation and became the official publication of the theosophical movement and its Society.
} 
research. The Society proposed a wide spectrum of inquiry, in order to test those facts often suspected of being fraud or the effect of delusion and superstition and to discuss theories and worldviews for a successive application within society ${ }^{23}$.

This extremely succinct review of the birth of parapsychology in the last quarter of the 19th century has not any pretence of confronting the complexities of those stories. Its only aim is to set the stage for considering the role of Schopenhauer in this crucial development of the history of the paranormal - when it became a substantial issue among researchers who often were prone to credulity but at the same time promoted a rational and scientific attitude towards spiritism. When we read about the intentions and realisations of those philosophers, physicians, and scientists, we can see something which is familiar with what we find in Schopenhauer and his "Essay on Spirit Seeing". They added experiments and research institutions - a non-negligible aspect, of course - but they started from the same presuppositions: there are facts who speak in favour of an extraordinary reality and those facts should not escape to reason and science - then a scientific investigation is needed. Instead of performing experiments, Schopenhauer extensively perused and discussed the neurophysiological literature of his time. He -the only one among the post-Kantian philosophers - pursued a more theoretical approach, but in the end he was expressing the same conviction that psychic research would manifest a few years later: the paranormal needed to be understood by science. Moreover, the fact of being credulous did not make the difference in all those societies for psychic research: Sidgwick was much more dubious than Wallace, and Richet was certain of the reality of ghosts. If still alive, Schopenhauer would probably have joined one of those associations.

A relevant question - one that rarely has been raised in literature - is whether Schopenhauer did play a substantial role in the rise of psychical research and the birth of parapsychology. His belonging to the prehistory of parapsychology is duly noted Ellenberger clearly states that he "was definitely among the ancestors of modern dynamic psychiatry" (Ellenberger, 205) and it is widely acknowledged his seminal role in Freud's elaboration of psychoanalytic notions ${ }^{24}$. My claim, here, is that Schopenhauer's approach to spiritism in the Parerga considered and indicated the new path. Such a guiding role is hardly deniable in Germany, where the Parerga were an editorial success and philosophers and scientists studied Schopenhauer's works. Corinna Treitel has admitted that Schopenhauer inspired "many of the first generation of German occultists in the 1870 and the 1880s" (Treitel, 36) but she seems to refer to his metaphysics and not to his methodological and scientific approach to the paranormal. Instead, we must not forget that Schopenhauer's way to philosophy of nature had a certain relevance among German scientists of the second half of the century - like Hermann von Helmholtz, Wilhelm Wundt, and Ewald Hering.

The question of Schopenhauer's presence in the emergence of psychical research in Europe is still to investigate, but I suggest two lines that can connect Schopenhauer's 1851 essay with the rise of parapsychology in the $188 \mathrm{os}$. The first one is the personal acquaintance of philosophers and physicians like Sidgwick, James, Bergson, Richet, and Janet with Schopenhauer's works. The second one is the relation which Ludwig Noiré in 1875 pointed out between Schopenhauer and Darwin - as evolutionists and, even more importantly, as monists - and which became a standard view in the intellectual Europe ${ }^{25}$. Wallace and the naturalists who accepted evolutionism and contributed to psychic research read or at least knew about Schopenhauer. Understanding this aspect of Schopenhauer's legacy in the birth

\footnotetext{
23 See Wolffram 2009, chapter 1.

${ }^{24}$ See Sulloway, 253.

${ }^{25}$ See Segala 2006 on the aspect of Schopenhauer's reception.
} 
of modern parapsychology goes beyond the scope of the present paper, but it might stimulate some scholars' curiosity and open a new line of investigation.

\section{References}

References to Schopenhauer's works are abbreviated according to the Bibliography below. Page numbers refer to the German edition and are followed by reference to the page number of the English translation as listed in the Bibliography.

ANDRIOPOULOS, Stefan. Ghostly Apparitions: German Idealism, the Gothic Novel, and Optical Media. New York: Zone Books, 2013.

BENSAUDE-VINCENT, Bernadette and Christine Blondel. Des savants face à l'occulte, 18701940. Paris: Éditions de la Découverte, 2002.

BERGSON, Henri. "Presidential Address". Proceedings of the Society for Psychical Research 26: 1913, pp. 462-79.

BAIMA BOLLONE, Pier Luigi. La scienza nel mondo degli spiriti. Torino: SEI, 1994.

BUTLER, Nicholas Murray. “The Progress of Psychical Research”. Popular Science Monthly 29: 1886, 482-91.

CARTWRIGHT, David E. "Schopenhauer's Haunted World. The Use of Weird and Paranormal Phenomena to Corroborate His Metaphysics". In The Oxford Handbook of Schopenhauer, 175-92. Ed. by Robert L. Wicks. Oxford: Oxford University Press, 2020.

EGO, Anneliese. Animalischer Magnetismus oder Aufklärung. Eine mentalitätsgeschichtliche Studie zum Konflikt um ein Heilkonzept im 18. Jahrhundert. Würzburg: Könighshausen und Nueman, 1991.

ELLENBERGER, Henri F. The Discovery of the Unconscious. The History and Evolution of Dynamic Psychiatry. New York: Basic Books, 1970 (1994).

FLOURENS, Pierre. Recherches expérimentales sur les propriété et le fonctions du système nerveux dans les animaux vertébrés. Second edition. Paris: Baillière, $\mathbf{1 8 4 2 .}$

HALL, Marshall. Abhandlungen über das Nervensystem. Aus dem Englischen mit Erläuterungen und Zusätzen von Dr. G. Kürschner, Privatdozent an der Universität Marburg. Marburg: Elwert, 1840.

HALL, Marshall. Grundzüge der Theorie und Praxis der innern Krankheiten nebst Betrachtungen über die wechselseitigen Beziehungen der Anatomie und Physiologie zur Pathologie und Therapie. Eine Reihe von Vorlesungen von Marshall Hall, aus dem Englischen von Dr. Levin. Leipzig: Kollmann, 1843.

HINES, Terence. Pseudoscience and the Paranormal. Amherst (NY): Prometheus Books, 2002 KOELLIKER, Rudolph Albert von. Die Selbständigkeit und Abhängigkeit des sympathischen Nervensystems, durch anatomische Beobachtungen bewiesen. Zürich: Meyer und Zeller, 1844.

LUKÁCS, György. Die Zerstörung der Vernunft. Darmstadt: Luchterhand, 1973.

MESMER, Franz Anton. Mesmerismus.Oder, System der Wechselwirkungen, Theorie und Anwendung des thierischen Magnetismus als die allgemeine Heilkunde zur Erhaltung des Menschen. Edited by Karl Christian Wolfart. Berlin: Nicolai, 1814. 
NOAKES, Richard. Physics and Psychics. The Occult and the Sciences in Modern Britain. Cambridge: Cambridge University Press, 2019.

NOIRÉ, Ludwig. Der monistische Gedanke. Eine Concordanz der Philosophie Schopenhauer's, Darwin's, R. Mayer's und L. Geiger's. Leipzig: Veit, 1875.

REIL, Johann Christian. "Ueber die Eigenschaften des Ganglien-Systems und sein Verhältnis zum Cerebral-System”. Archiv für die Physiologie 7: 1807, 189-254.

SAWICKI, Diethard. Leben mit den Toten: Geisterglauben und die Entstehung des Spiritismus in Deutschland, 1770-1900. Munich: Schöningh, 2002.

SCARPELLI, Giacomo. Il cranio di cristallo. Evoluzione della specie e spiritualismo. Torino: Bollati Boringhieri, 1993.

SCHOPENHAUER, Arthur.

$\mathrm{N}$ Ueber den Willen in der Natur. Eine Erörterung der Bestätigungen, welche die Philosophie des Verfassers, seit ihrem Auftreten, durch die empirischen Wissenschaften erhalten hat. Vol. 5 of Sämtliche Sämtliche Werke, edited by Arthur Hübscher. Wiesbaden: Brockhaus, 1972 / On Will in Nature. In On the Fourfold Root of the Principle of Sufficient Reason and Other Writings, edited by D. E. Cartwright, E. E. Erdmann, C. Janaway. Cambridge: Cambridge University Press, 2012.

PI Parerga und Paralipomena: kleine philosophische Schriften, I. Vol. 5 of Sämtliche Sämtliche Werke, edited by Arthur Hübscher. Wiesbaden: Brockhaus, 1972 / Parerga and Paralipomena, 1. edited by E. F. J. Payne. Oxford: Clarendon Press, 1974.

HNI Der handschriftliche Nachlaß, Band 1: Frühe Manuskripte (1804-1818), in Der handschriftliche Nachlaß in fünf Bänden, hrsg. von Arthur Hübscher, München, Deutscher Taschenbuch Verlag, 1985 / Manuscript Remains, Vol. 1. Translated by E. F. J. Payne. Oxford: Berg, 1988.

SEGALA, Marco. I fantasmi, il cervello, l'anima. Schopenhauer, l'occulto e la scienza. Firenze: Olschki, 1998.

SEGALA, Marco. "Schopenhauer and Monism", Jahrbuch für Europäische Wissenschaftskultur 3: 2007, 165-175.

SEGALA, Marco. "Schopenhauer and the empirical confirmations of philosophy". Idealistic Studies 40: 2010, 27-41.

SIDGWICK, Henry. "The canons of evidence in psychical research". Proceedings of the Society for Phsychical Research 6: 1889, 1-6.

SULLOWAY, Frank J. Freud, Biologist of the Mind: Beyond the Psychoanalytic Legend. New York: Basic Books, 1979 (1992).

TREITEL, Corinna. A Science for the Soul: Occultism and the Genesis of the German Modern. Baltimore: The Johns Hopkins University Press, 2004.

WOLFFRAM, Heather. The Stepchildren of Science Paranormal in Germany. Psychical Research and Parapsychology in Germany, c.1870-1939. Amsterdam - New York: Rodopi, 2009. 